\title{
Assessment of the Water and Sediment Quality of Tropical Forest Streams in Upper Reaches of the Baleh River, Sarawak, Malaysia, Subjected to Logging Activities
}

\author{
Teck-Yee Ling, ${ }^{1}$ Chen-Lin Soo, ${ }^{1}$ Jagath-Retchahan Sivalingam, ${ }^{1}$ Lee Nyanti, ${ }^{2}$ \\ Siong-Fong Sim, ${ }^{1}$ and Jongkar Grinang ${ }^{3}$ \\ ${ }^{1}$ Department of Chemistry, Faculty of Resource Science and Technology, Universiti Malaysia Sarawak, \\ 94300 Kota Samarahan, Sarawak, Malaysia \\ ${ }^{2}$ Department of Aquatic Science, Faculty of Resource Science and Technology, Universiti Malaysia Sarawak, \\ 94300 Kota Samarahan, Sarawak, Malaysia \\ ${ }^{3}$ Institute of Biodiversity and Environmental Conservation, Universiti Malaysia Sarawak, 94300 Kota Samarahan, \\ Sarawak, Malaysia
}

Correspondence should be addressed to Teck-Yee Ling; teckyee60@gmail.com

Received 12 January 2016; Revised 24 February 2016; Accepted 2 March 2016

Academic Editor: Pedro Ávila-Pérez

Copyright (C) 2016 Teck-Yee Ling et al. This is an open access article distributed under the Creative Commons Attribution License, which permits unrestricted use, distribution, and reproduction in any medium, provided the original work is properly cited.

The study of the impact of logging activities on water and sediment quality of Sarawak forest streams is still scarce despite Sarawak being the largest exporter of timber in Malaysia. This study was aimed at determining the water and sediment quality of forest streams in Sarawak and the potential impact of logging activities. In situ parameters were measured, and water and sediment samples were collected at six stations before rain. Additionally, water quality was investigated at three stations after rain. The results showed that canopy removal resulted in large temperature variation and sedimentation in the forest streams. Lower suspended solids were found at stations with inactive logging $(<2 \mathrm{mg} / \mathrm{L})$ compared to active logging $(10-16 \mathrm{mg} / \mathrm{L})$ activities. The highest concentration of total nitrogen and total phosphorus in water and sediment was $4.4 \mathrm{mg} / \mathrm{L}, 77.6 \mu \mathrm{g} / \mathrm{L}, 0.17 \%$, and $0.01 \%$, respectively. Besides, significantly negative correlation of sediment nitrogen and water total ammonia nitrogen indicated the loss of nitrogen from sediment to water. Water quality of the streams deteriorated after rain, in particular, suspended solids which increased from $8.3 \mathrm{mg} / \mathrm{L}$ to $104.1 \mathrm{mg} / \mathrm{L}$. This study reveals that logging activities have an impact on the water quality of Sarawak forest streams particularly in rainfall events.

\section{Introduction}

Sarawak is the largest state in Malaysia with about $70 \%$ of the state categorized as forested land. Sarawak's forestry plays a significant role in its socioeconomic development. In 2012, the export earnings from timber and timber products in Sarawak were 2.4 billion USD [1]. The majority of Sarawak forests are subjected to logging which has been a major contributor to the Malaysian economy. It has been reported that Sarawak exported a total of $1,388,894 \mathrm{~m}^{3}$ of logs worth 244 million USD from January to June 2015, contributing $88.7 \%$ compared to Sabah's $10.5 \%$ and West Malaysia's $0.8 \%$ [2]. The high production of timber renders deforestation problems in
Sarawak. Deforestation and degradation of forests in Sarawak are occurring at a rate of $0.64 \%$ annually [3]. Nearly $80 \%$ of the land surface of Sarawak was impacted by previously undocumented, high-impact logging or clearing operations from 1990 to 2009 [4].

Deforestation often results in the degradation of water quality which includes an increase in temperature, sedimentation, and nutrient enrichment [5-9]. In Malaysia, soil loss from logging activities had been predicted to highlight the potential risk posed by logging within water catchment areas [10]. Besides, the amounts of sediment, wood, and detritus accumulations were examined in four headwater tributaries after timber harvesting in the Bukit Tarek Experimental 
Watershed, Peninsular Malaysia [11]. Recently, [12] studied the effects of logging activities on ecological water quality indicators in the Berasau River, Johor, Malaysia. However, less attention has been paid to Sarawak forest streams despite the fact that Sarawak is the largest exporter of logs in Malaysia. Hence, the water and sediment quality of Sarawak forest streams that are subjected to logging activities were collected in order to investigate the potential impact of the logging activities on the streams.

The forest streams selected in the present study were located at the upper reaches of the main tributaries of Batang Baleh. Batang Baleh is one of the main tributaries of the Rajang River $(551 \mathrm{~km})$ which is the longest river in Malaysia. This river flows through the Kapit Division which is a mountainous region mostly ( $80 \%$ ) covered by dense primary forests. Most of the 534 longhouses in the division are located along major rivers and tributaries of the Rajang River. Thus, the Rajang River and its tributaries are the main means of transportation in the division. A hydroelectric project has been proposed at Batang Baleh. Dam construction is often associated with environmental degradation and water quality deterioration [13-22]. However, different anthropogenic sources make it difficult to identify the pollution sources on the river once a dam is constructed, thereby making it rather complex to assess the true impact of dam construction alone. Hence, this study is necessitated to serve as baseline data for any potential mitigation measures if or where necessary, in the future.

\section{Materials and Methods}

2.1. Study Area and Sampling Stations. The study area is located at the hill forest land [23] characterized as mixed dipterocarp forest (MDF) and secondary forest in Sarawak, Malaysia [24]. The lands are covered mainly by the RedYellow Podzolic soils in the Sarawak classification system [25]. The Red-Yellow Podzolic soils of both river basins consist of sandstone and shale bedrocks from the Belaga and Nyalau Formations [26]. Annual rainfall as measured at Kapit ( $45 \mathrm{~km}$ from the study area) is among the highest ones found in Sarawak which exceeds $5000 \mathrm{~mm}$ in most years. There is usually an average of 250 days per year of measureable precipitation. Temperature is high throughout the year with a mean annual daily maximum temperature of $33^{\circ} \mathrm{C}$ [27]. Field sampling was carried out at the upper reaches of two main tributaries of Batang Baleh ("batang" denotes big river) (coordinates: $2^{\circ} 1^{\prime} 0^{\prime \prime} \mathrm{N}$ and $113^{\circ} 1^{\prime} 1^{\prime \prime} \mathrm{E}$ ), namely, Sg. Gaat and Sg. Mengiong in Sarawak (Figure 1). All sampling stations were located at the upper reaches of the two tributaries. Station 1 was located at the right tributaries of Sg. Mengiong, namely, Sg. Ugak, while station 2 and station 3 were located at the left tributaries of Sg. Mengiong, namely, Sg. Meranu and $\mathrm{Sg}$. Entajum. Station 4 was located upstream of Sg. Gaat while station 5 and station 6 were located at Sg. Marang and Sg. Ramong which are the right tributaries of Sg. Gaat. Presently, the study area is subjected to extensive land use activities from commercial timber harvesting, Acacia tree plantation, and subsistence farming. Land use activities nearby each of the sampling stations are given in Table 1. In addition, station coordinates, sampling regime, and weather condition during sampling were also included in Table 1.

2.2. Field Collection and Laboratory Analysis. Water quality was investigated by measuring in situ parameters and, for ex situ analyses, water and sediment samples were collected at six sampling stations (stations 1-6) on a sunny day while the in situ parameters measurement and water samples were collected at three sampling stations (stations 4-6) after a rainfall event (Table 1). In situ parameters including temperature, $\mathrm{pH}$, and conductivity were measured using a $\mathrm{pH}$ meter (Orion 3 Star, Thermo Scientific) and a microprocessor $\mathrm{pH}$ meter (TI9000, Walklab), respectively. Dissolved oxygen (DO), turbidity, transparency, depth, and flow velocity were measured using a DO meter (ExStik ${ }^{\circledR}$ II, Extech EC600), a turbidity meter (Mi415, Milwaukee), a Secchi disc with measuring tape, a depth sounder (PS-7, Hondex), and a stream flowmeter (Geopacks), respectively.

Triplicate water samples were taken for the analysis of chlorophyll $a$ (chl- $a$ ), total suspended solids (TSS), fiveday biochemical oxygen demand $\left(\mathrm{BOD}_{5}\right)$, chemical oxygen demand (COD), total nitrogen (TN), total ammonia nitrogen (TAN), nitrite nitrogen $\left(\mathrm{NO}_{2}{ }^{-} \mathrm{N}\right)$, nitrate nitrogen $\left(\mathrm{NO}_{3}{ }^{-}\right.$$\mathrm{N})$, total phosphorus (TP), soluble reactive phosphorus (SRP), and total sulphide (TS). All sampling bottles were acidwashed, cleaned, and dried before use. Sediment samples were kept in sediment plastic bags for the analysis of sediment $\mathrm{pH}$, water content, organic matter (OM), total organic carbon (TOC), total phosphorus (TP), and total nitrogen (TN). Analysis of $\mathrm{BOD}_{5}, \mathrm{TAN}, \mathrm{NO}_{2}{ }^{-}-\mathrm{N}, \mathrm{NO}_{3}{ }^{-}-\mathrm{N}, \mathrm{SRP}$, and TS was conducted in the field immediately after sampling. Water samples (acidified to $\mathrm{pH}<2$ ) and sediment samples were placed in an ice box and transported to the laboratory for further analysis [28].

For water analysis, the triplicate samples were composited prior to analyses. All water analyses were performed according to standard procedures in triplicate unless otherwise mentioned [28, 29]. Concentrations of chl- $a$ were determined from adequate samples filtered through $0.7 \mu \mathrm{m}$ glass fibre filter (Sartorius Stedim MGF) and extracted for $24 \mathrm{~h}$ using $90 \%(\mathrm{v} / \mathrm{v})$ acetone. TSS were assayed as the difference between initial and final weight of the $1.2 \mu \mathrm{m}$ retention glass fibre filter (Sartorius Stedim MGC), after filtration of an adequate sample volume and drying at $105^{\circ} \mathrm{C} . \mathrm{BOD}_{5}$ was determined as the difference between initial and five-day DO content, after five-day incubation of the undiluted sample. COD was determined by closed reflux titrimetric method [28]. TN and TAN were determined by persulfate method and Nessler's method, respectively [28]. $\mathrm{NO}_{2}{ }^{-}-\mathrm{N}$ and $\mathrm{NO}_{3}{ }^{-}$$\mathrm{N}$ were determined by diazotization method (low range) and cadmium reduction method, respectively [29]. Water sample was filtered through a $0.7 \mu \mathrm{m}$ glass fibre filter (Sartorius Stedim MGF) prior to the analysis of TAN, $\mathrm{NO}_{2}{ }^{-}-\mathrm{N}$, and $\mathrm{NO}_{3}{ }^{-}-\mathrm{N}$. TP was determined by ascorbic acid method after persulfate digestion of samples [28]. SRP was determined by the colorimetric ascorbic acid method [29] after filtration 
TABLE 1: The sampling regime and description of the six stations surveyed in the present study.

\begin{tabular}{|c|c|c|c|}
\hline Station & Date & Weather & Description of the sampling station \\
\hline $\begin{array}{l}\text { Station } 1 \text { : } \\
\text { Sg. Ugak } \\
\text { N } 01^{\circ} 38^{\prime} 46.1^{\prime \prime} \\
\text { E } 113^{\circ} 07^{\prime} 47.1^{\prime \prime}\end{array}$ & $6 / 8 / 2014$ & Sunny & $\begin{array}{l}\text { Old secondary forest with partly open canopy cover } \\
\text { Profuse sedimentation and heavy erosion on riverbanks } \\
\text { Presence of logging activities }\end{array}$ \\
\hline $\begin{array}{l}\text { Station 2: } \\
\text { Sg. Meranu } \\
\mathrm{N} 01^{\circ} 30^{\prime} 57.4^{\prime \prime} \\
\mathrm{E} 113^{\circ} 14^{\prime} 41.4^{\prime \prime}\end{array}$ & $6 / 8 / 2014$ & Sunny & $\begin{array}{l}\text { Old secondary forest with partly open canopy cover } \\
\text { Slight bottom sedimentation } \\
\text { Presence of logging activities and replantation }\end{array}$ \\
\hline $\begin{array}{l}\text { Station 3: } \\
\text { Sg. Entajum } \\
\text { N } 01^{\circ} 33^{\prime} 37.8^{\prime \prime} \\
\text { E } 113^{\circ} 05^{\prime} 01.2^{\prime \prime}\end{array}$ & $7 / 8 / 2014$ & Sunny & $\begin{array}{l}\text { Old secondary forest with open canopy cover } \\
\text { Presence of riparian vegetation, trees, grasses, shrubs, } \\
\text { and herbs } \\
\text { Slight bottom sedimentation } \\
\text { Inactive logging activities }\end{array}$ \\
\hline $\begin{array}{l}\text { Station } 4 \text { : } \\
\text { Sg. Gaat } \\
\text { N } 01^{\circ} 38^{\prime} 54.0^{\prime \prime} \\
\text { E } 113^{\circ} 04^{\prime} 53.6^{\prime \prime} \\
\end{array}$ & $\begin{array}{l}6 / 8 / 2014 \\
8 / 8 / 2014\end{array}$ & $\begin{array}{l}\text { Before rain with thunder } \\
\text { Raining }\end{array}$ & $\begin{array}{l}\text { Old secondary forest with open canopy cover } \\
\text { Slight bottom sedimentation } \\
\text { Presence of logging activities }\end{array}$ \\
\hline $\begin{array}{l}\text { Station 5: } \\
\text { Sg. Marang } \\
\text { N } 01^{\circ} 38^{\prime} 04.7^{\prime \prime} \\
\text { E } 113^{\circ} 05^{\prime} 21.8^{\prime \prime} \\
\end{array}$ & $\begin{array}{l}7 / 8 / 2014 \\
8 / 8 / 2014\end{array}$ & $\begin{array}{l}\text { Sunny } \\
\text { Raining }\end{array}$ & $\begin{array}{l}\text { Old secondary forest with open canopy cover } \\
\text { Inactive logging activities } \\
\text { Replantation of softwood }\end{array}$ \\
\hline $\begin{array}{l}\text { Station 6: } \\
\text { Sg. Ramong } \\
\text { N } 01^{\circ} 38^{\prime} 49.7^{\prime \prime} \\
\text { E } 113^{\circ} 07^{\prime} 48.6^{\prime \prime}\end{array}$ & $\begin{array}{l}7 / 8 / 2014 \\
8 / 8 / 2014\end{array}$ & $\begin{array}{l}\text { Sunny } \\
\text { Raining }\end{array}$ & $\begin{array}{l}\text { Old secondary forest with open canopy cover } \\
\text { Slight bottom sedimentation } \\
\text { Active logging activities at approximately } 5 \mathrm{~km} \\
\text { upstream }\end{array}$ \\
\hline
\end{tabular}

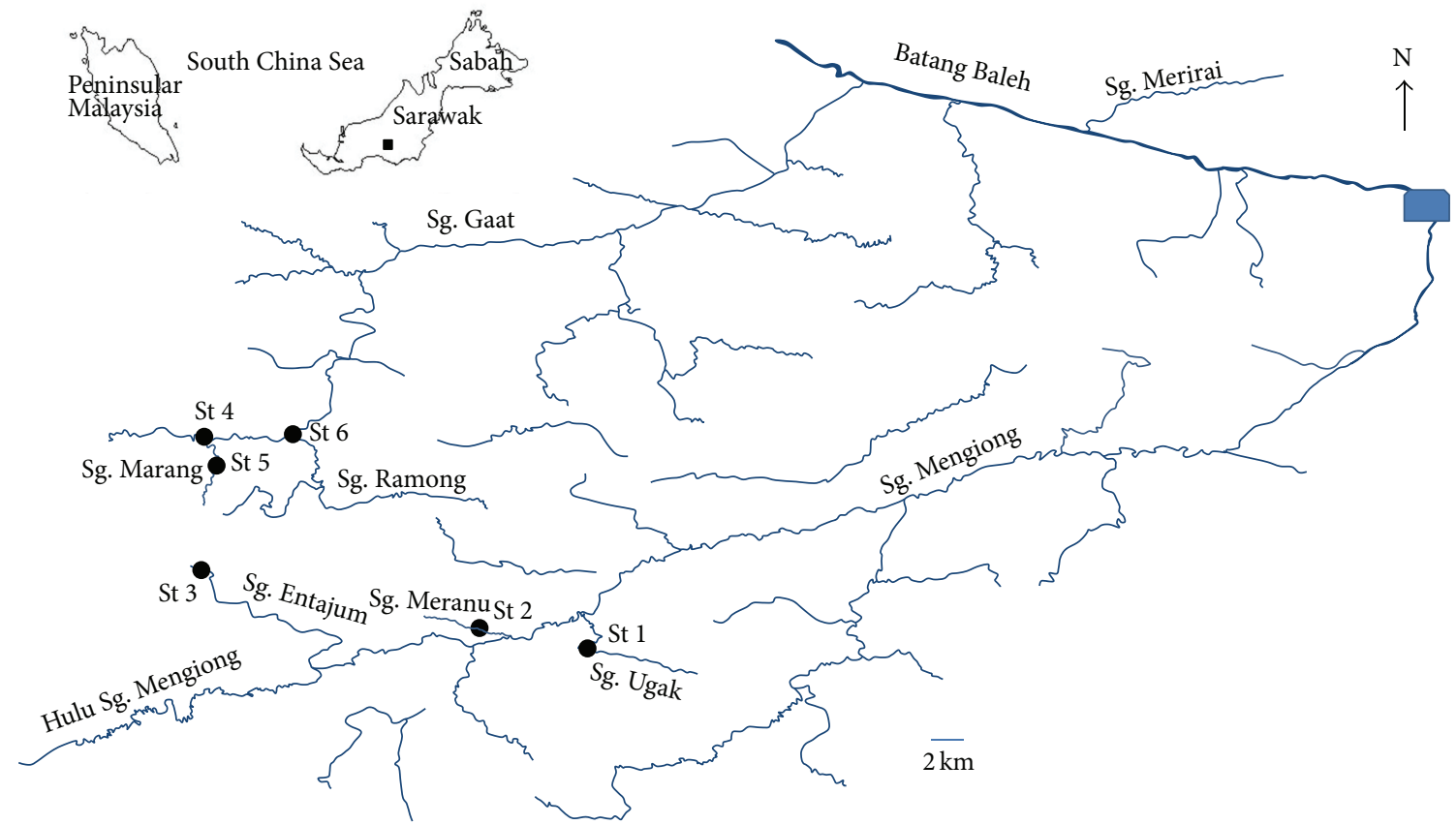

Study area

- Sampling station

Planned Baleh Dam site

FIgURE 1: The study area in Sarawak state and location of the sampling stations in the present study. 
through a $0.45 \mu \mathrm{m}$ cellulose acetate membrane filter (Sartorius Stedim). TS was analyzed using the methylene blue method [29]. $\mathrm{H}_{2} \mathrm{~S}$ was calculated according to [28] with the following equation:

$$
\mathrm{H}_{2} \mathrm{~S}=\frac{\mathrm{TS}}{10^{\mathrm{pH}-\mathrm{pK}^{\prime}}}+1,
$$

where $\mathrm{H}_{2} \mathrm{~S}$ is unionized hydrogen sulphide, TS is total sulphide, and $\mathrm{pK}^{\prime}$ is conditional first dissociation constant of hydrogen sulphide for freshwater.

Calibration curve was constructed for each chemical analysis. Blank and standard solutions were treated in a similar way as the sample. The detection limits for TAN, $\mathrm{NO}_{2}{ }^{-}$$\mathrm{N}, \mathrm{NO}_{3}{ }^{-}-\mathrm{N}, \mathrm{TN}, \mathrm{SRP}, \mathrm{TP}$, and TS were $0.097 \mathrm{mg} / \mathrm{L}, 0.01 \mathrm{mg} / \mathrm{L}$, $0.01 \mathrm{mg} / \mathrm{L}, 0.335 \mathrm{mg} / \mathrm{L}, 3 \mu \mathrm{g} / \mathrm{L}, 12 \mu \mathrm{g} / \mathrm{L}$, and $0.01 \mathrm{mg} / \mathrm{L}$, respectively.

For sediment analysis, $\mathrm{pH}$ value of sediment was determined from a mixture of $10 \mathrm{~g}$ of air-dried sediment sample and $10 \mathrm{~mL}$ of deionized water [30]. After 10 minutes of stirring, the $\mathrm{pH}$ was measured from the suspension by using a $\mathrm{pH}$ meter (Orion 3 Star, Thermo Scientific). Water content of a sediment sample was assayed as the difference between initial and final weight of the sediment after drying at $105^{\circ} \mathrm{C}$ [31]. Sediment samples were air-dried and sieved using a $<0.5 \mathrm{~mm}$ sieve for the determination of OM, TOC, TP, and TN. Organic matter and TOC were determined by losson-ignition method and Walkley-Black method, respectively [32]. Total phosphorus was determined by ascorbic acid method after perchloric digestion of samples [33]. Total nitrogen was determined by cadmium reduction method [29] after persulfate digestion of samples [28]. Calibration curve was constructed for TP and TN analyses. Blank and standard solutions were treated in a similar way as the sample. Particle size analysis was done according to the pipette method of [34].

2.3. Water Quality Index (WQI). Water quality index (WQI) which combines the six variables of DO, BOD, COD, TSS, $\mathrm{AN}$, and $\mathrm{pH}$ was calculated according to the equation of department of environment [35]:

$$
\begin{aligned}
\mathrm{WQI}= & 0.22 * \mathrm{SI}_{\mathrm{DO}}+0.19 * \mathrm{SI}_{\mathrm{BOD}}+0.16 * \mathrm{SI}_{\mathrm{COD}} \\
& +0.15 * \mathrm{SI}_{\mathrm{AN}}+0.16 * \mathrm{SI}_{\mathrm{SS}}+0.12 * \mathrm{SI}_{\mathrm{pH}}
\end{aligned}
$$

where SI indicates the subindex for each parameter, $\mathrm{SI}_{\mathrm{DO}}$ is subindex $\mathrm{DO}$ (\% saturation), $\mathrm{SI}_{\mathrm{BOD}}$ is subindex $\mathrm{BOD}(\mathrm{mg} / \mathrm{L})$, $\mathrm{SI}_{\mathrm{COD}}$ is subindex $\mathrm{COD}(\mathrm{mg} / \mathrm{L}), \mathrm{SI}_{\mathrm{AN}}$ is subindex $\mathrm{AN}(\mathrm{mg} / \mathrm{L})$, $\mathrm{SI}_{\mathrm{SS}}$ is subindex $\mathrm{SS}(\mathrm{mg} / \mathrm{L})$, and $\mathrm{SI}_{\mathrm{pH}}$ is subindex $\mathrm{pH}$.

2.4. Statistical Analysis. All data were tested for normality and equality of variance with Shapiro-Wilk test and Levene's test, respectively. The nonparametric test was used in the subsequent statistical analysis due to the violation of the normal distribution and equal variance assumptions of the parametric tests. The Kruskal-Wallis test was carried out to determine if there was any significant difference in the results between the six sampling stations. The Wilcoxon sign-rank test was used to compare the results between a sunny day before rain and that after rain. The Spearman rank correlation was used to determine the relationship among all the parameters. Cluster analysis (CA) was used to investigate the grouping of the six sampling stations. $Z$-score standardization of the variables and Ward's method using Euclidean distances as a measure of similarity were used. All the statistical analyses were carried out by the Statistical Software for Social Sciences (SPSS Version 22, SPSS, Inc., 1995).

\section{Results}

3.1. In Situ Water Quality Parameters. Figure 2 illustrates the in situ parameters collected at the six sampling stations. Station 4 which was located at the main stream of Sg. Gaat was the deepest station $(72.7 \pm 1.5 \mathrm{~cm})$ with the highest flow rate $(0.112 \pm 0.001 \mathrm{~m} / \mathrm{s})$ compared to the other stations. Station 4 was significantly deeper than stations 1,2 , and 3 ( $p$ value $\leq$ 0.05 ) and the stream flow velocity was significantly faster than stations 3,5 , and 6 ( $p$ value $\leq 0.05$ ). Besides, stations 1,2 , and 3 which were located at the tributaries of Sg. Mengiong were shallower than tributaries of Sg. Gaat, particularly, station 3, which was significantly shallower than station 5 ( $p$ value $=$ $0.006)$ and station $6(p$ value $=0.039)$.

Temperature of the streams ranged from $24.7 \pm 0.2^{\circ} \mathrm{C}$ to $28.8 \pm 0.3^{\circ} \mathrm{C}$. Temperature at station 3 was significantly lower than stations 4,5 , and 6 ( $p$ value $\leq 0.05$ ) while temperature of station 1 was significantly lower than stations 5 and $6(p$ value $\leq 0.05)$. All the streams were generally well-aerated with the mean DO value of $6.8 \mathrm{mg} / \mathrm{L}$. Dissolved oxygen at stations 1 and 4 was significantly higher than stations 3 and 5 ( $p$ value $\leq 0.05$ ). The $\mathrm{pH}$ value of the streams ranged from $7.00 \pm 0.02$ to $7.74 \pm 0.03$. The highest $\mathrm{pH}$ value recorded at station 4 was significantly higher than stations 2,3 , and 6 ( $p$ value $\leq 0.05)$. Conductivity value of the streams ranged from $25.9 \pm 0.1 \mu \mathrm{S} \mathrm{cm}^{-1}$ to $49.1 \pm 0.6 \mu \mathrm{S} \mathrm{cm}^{-1}$. The lowest value was recorded at station 1 whereas the highest value was recorded at station 4 . The conductivity value at station 4 was significantly higher than stations 1,2 , and 6 ( $p$ value $\leq$ $0.05)$ whereas station 1 was significantly lower than stations 3,4 , and 5 ( $p$ value $\leq 0.05$ ). All the streams were clear as indicated by the low turbidity and high transparency values. The turbidity value ranged from $1.5 \pm 0.0 \mathrm{NTU}$ to $7.7 \pm$ $0.0 \mathrm{NTU}$ while the transparency value was almost the same with the depth of the stream except for station 5 and station 6.

3.2. Ex Situ Water Quality Parameters. Figure 3 illustrates the ex situ water quality parameters of the six sampling stations in the present study. The lowest and the highest chla concentrations were found at station $1\left(0.3 \pm 0.1 \mathrm{mg} / \mathrm{m}^{3}\right)$ and station $3\left(2.3 \pm 0.1 \mathrm{mg} / \mathrm{m}^{3}\right)$, respectively. Chlorophyll $a$ at station 1 was significantly lower than stations 3,5 , and $6(p$ value $\leq 0.05$ ) while chl- $a$ at station 3 was significantly higher than stations 1,2 , and 4 ( $p$ value $\leq 0.05$ ). Total suspended solids were low at stations 3 and $5(\approx 2 \mathrm{mg} / \mathrm{L})$ and the highest TSS was found at station $1(16.3 \pm 1.5 \mathrm{mg} / \mathrm{L})$. Total suspended 


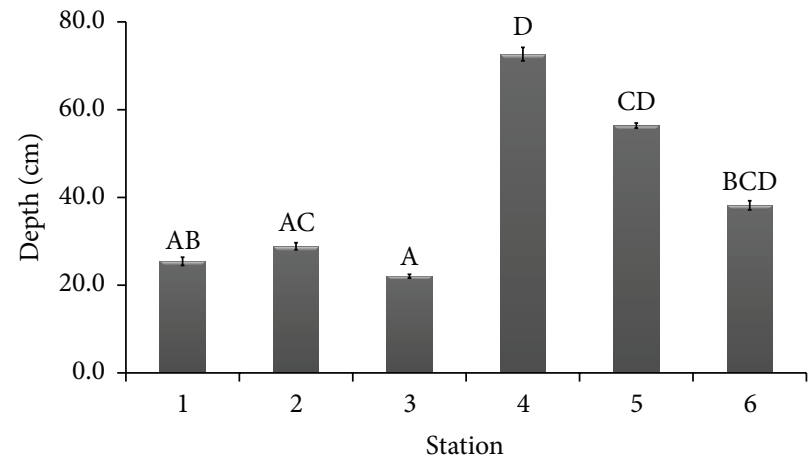

(a)

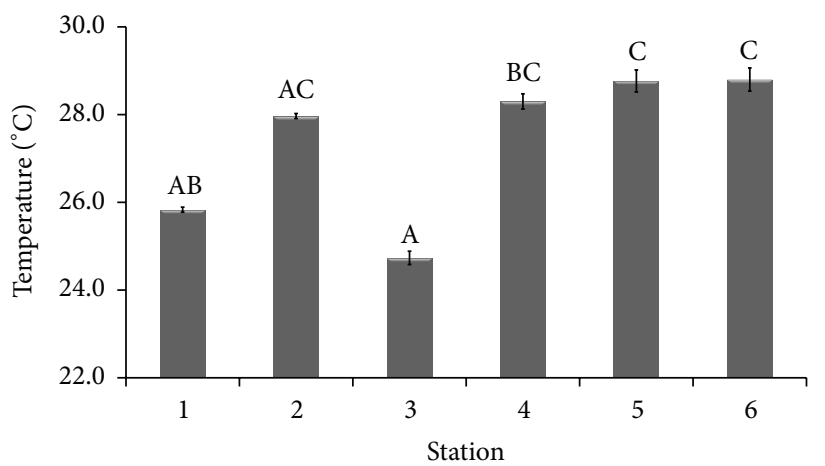

(c)

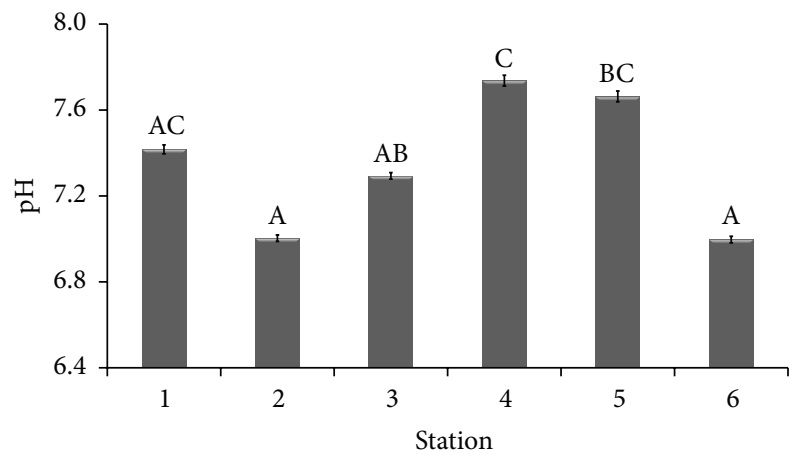

(e)

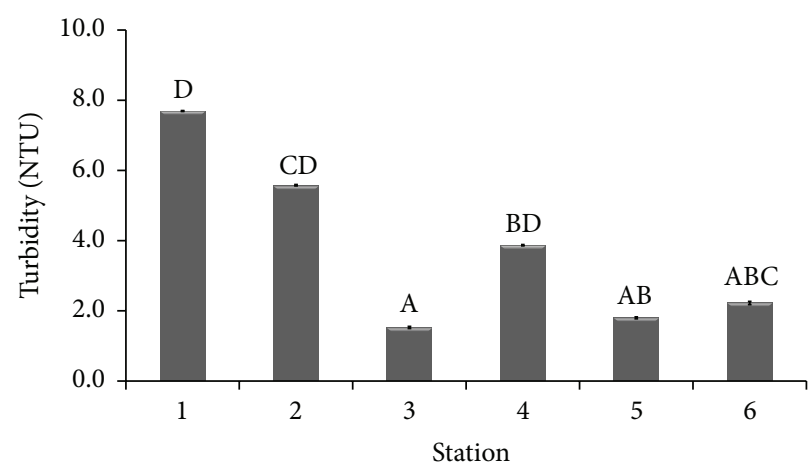

(g)

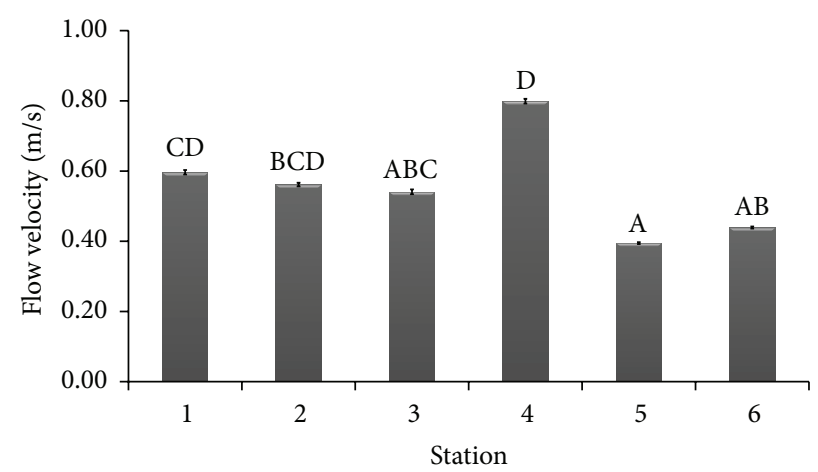

(b)

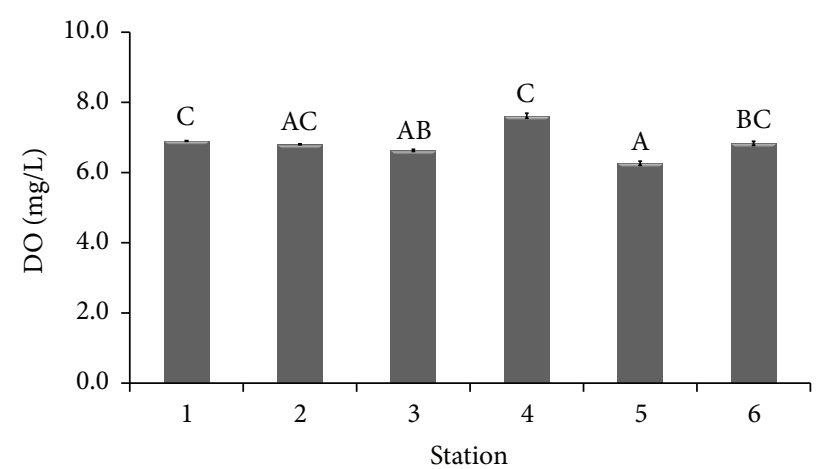

(d)

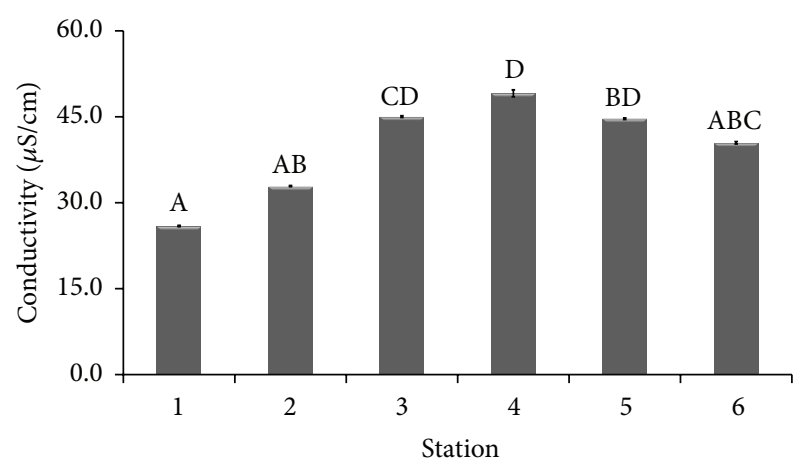

(f)

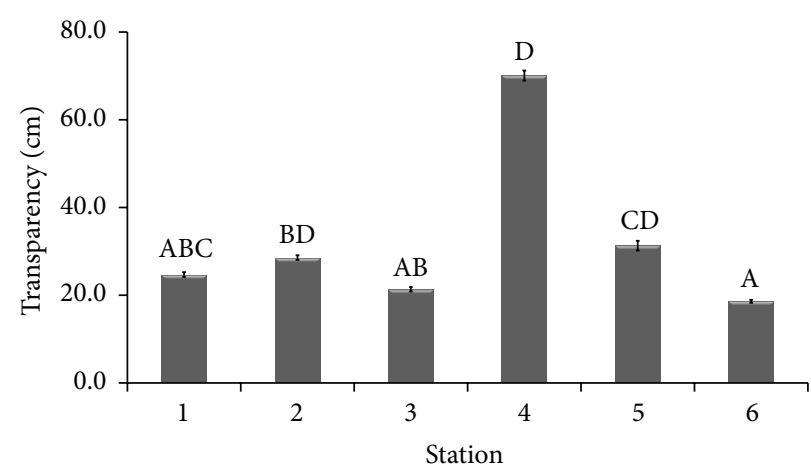

(h)

FIGURE 2: In situ water quality parameters of (a) depth, (b) flow velocity, (c) temperature, (d) DO, (e) pH, (f) conductivity, (g) turbidity, and (h) transparency collected at the six sampling stations located at the upper reaches of two main tributaries of Batang Baleh (different letters indicate significant difference at $p$ value $\leq 0.05$ ). 


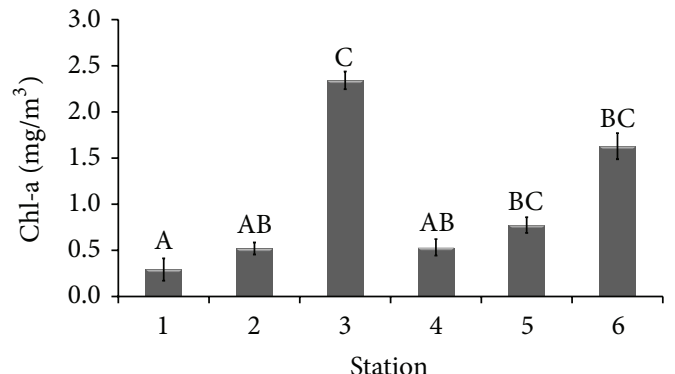

(a)

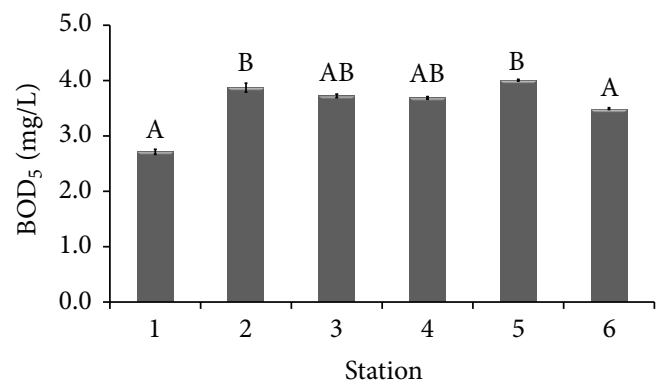

(c)

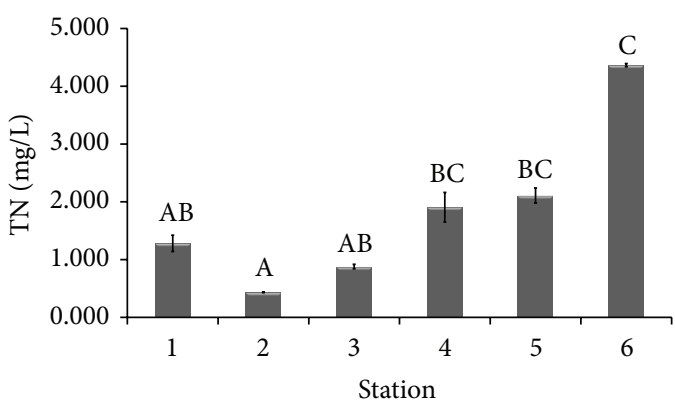

(e)

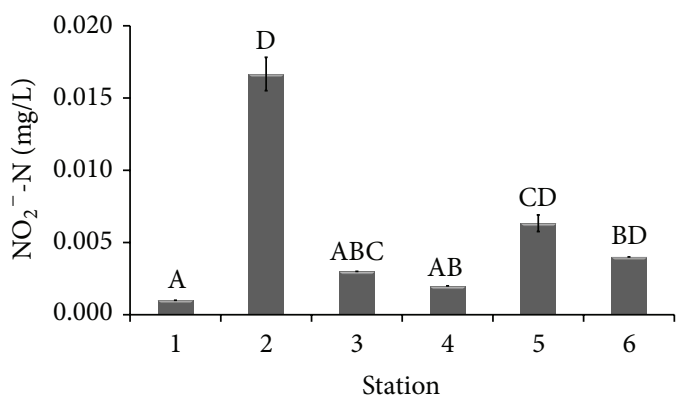

(g)

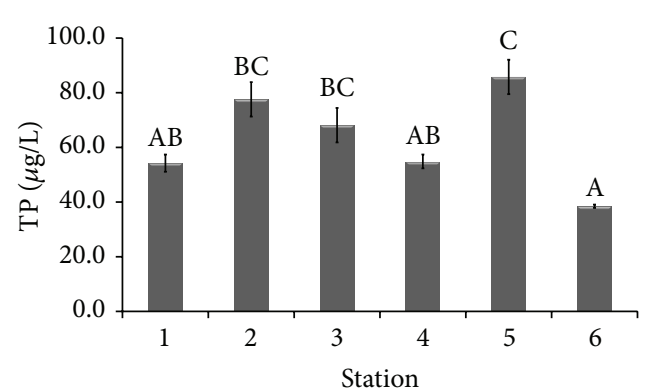

(i)

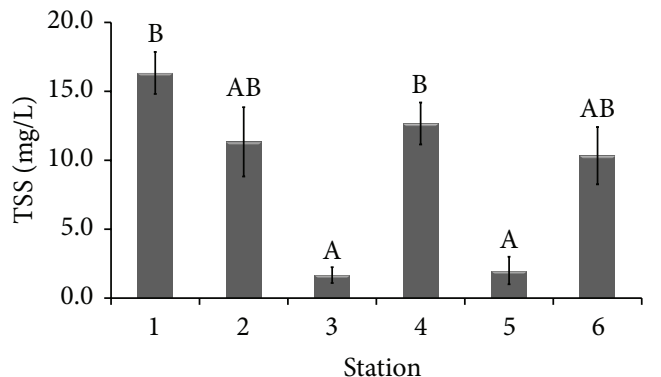

(b)

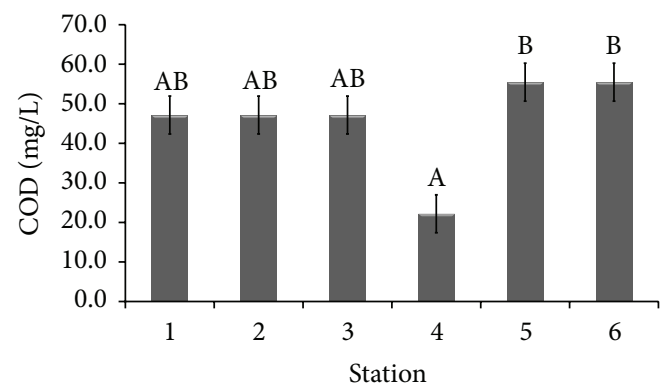

(d)

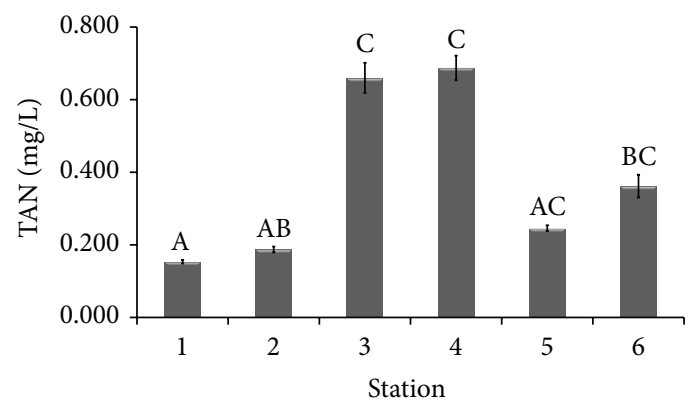

(f)

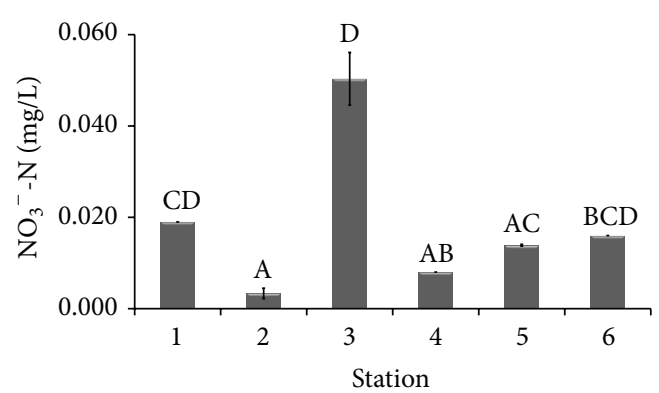

(h)

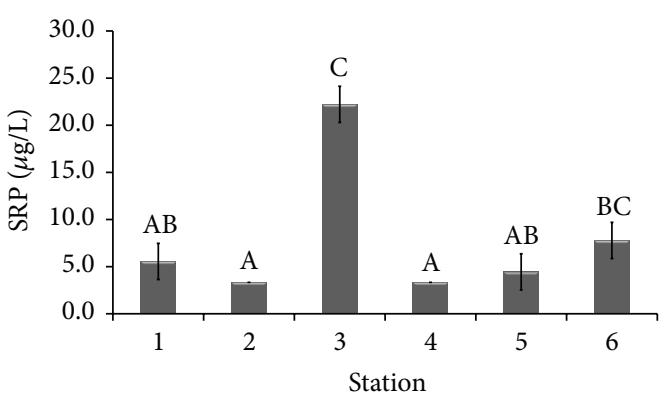

(j)

Figure 3: Continued. 


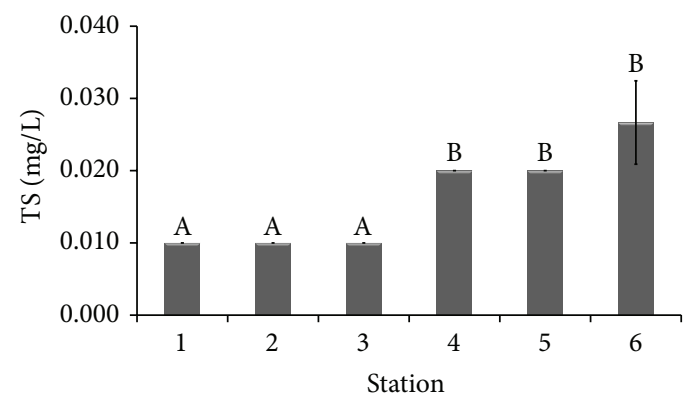

$(\mathrm{k})$

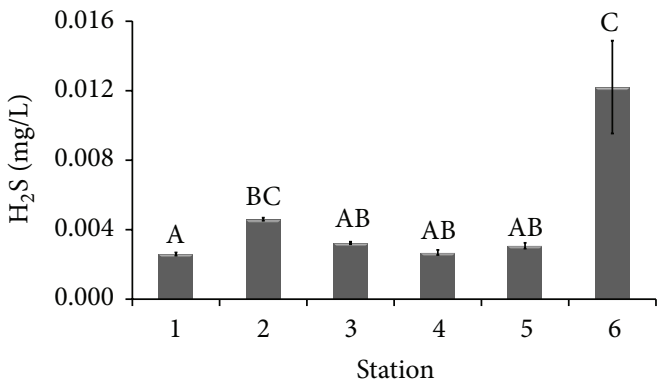

(1)

FIGURE 3: Ex situ water quality of (a) chlorophyll $a$ (chl-a), (b) total suspended solids (TSS), (c) five-day biochemical oxygen demand (BOD 5 ), (d) chemical oxygen demand (COD), (e) total nitrogen (TN), (f) total ammonia nitrogen (TAN), (g) nitrite nitrogen ( $\left.\mathrm{NO}_{2}{ }^{-}-\mathrm{N}\right),(\mathrm{h})$ nitrate nitrogen $\left(\mathrm{NO}_{3}{ }^{-}-\mathrm{N}\right)$, (i) total phosphorus (TP), (j) soluble reactive phosphorus (SRP), (k) total sulphide (TS), and (l) hydrogen sulphide ( $\mathrm{H}_{2} \mathrm{~S}$ ) collected at the six sampling stations located at the upper reaches of two main tributaries of Batang Baleh (different letters indicate significant difference at $p$ value $\leq 0.05$ ).

solids were significantly higher at stations 1 and 4 compared to stations 3 and 5 ( $p$ value $\leq 0.05$ ). Five-day biochemical oxygen demand ranged from $2.7 \pm 0.0 \mathrm{mg} / \mathrm{L}$ to $4.0 \pm 0.0 \mathrm{mg} / \mathrm{L}$. Stations 2 and 5 were significantly higher than stations 1 and 6 ( $p$ value $\leq 0.05$ ). The lowest COD value was found at station 4 $(22.2 \pm 4.8 \mathrm{mg} / \mathrm{L})$ which was significantly lower than stations 5 and 6 ( $p$ value $\leq 0.05$ ).

Total nitrogen at stations 1,2 , and 3 which were located at Sg. Mengiong $(0.434 \pm 0.006$ to $1.282 \pm 0.142 \mathrm{mg} / \mathrm{L})$ was generally lower than stations 4,5 , and 6 which were located at Sg. Gaat (1.907 \pm 0.256 to $4.366 \pm 0.028 \mathrm{mg} / \mathrm{L})$. Additionally, total nitrogen at stations 1,2 , and 3 was significantly lower than station 6 ( $p$ value $\leq 0.05$ ). Total ammonia nitrogen was high at stations 3 and $4(\approx 0.674 \mathrm{mg} / \mathrm{L})$ and low at stations 1 and $2(\approx 0.171 \mathrm{mg} / \mathrm{L})$. Stations 3 and 4 were significantly higher than station 1 ( $p$ value $\leq 0.05$ ). The highest $\mathrm{NO}_{2}{ }^{-}-\mathrm{N}$ concentration was found at station $2(0.017 \pm 0.001 \mathrm{mg} / \mathrm{L})$ which was significantly higher than stations 1,3 , and 4 ( $p$ value $\leq 0.05$ ). The highest $\mathrm{NO}_{3}{ }^{-}-\mathrm{N}$ concentration was found at station $3(0.050 \pm 0.006 \mathrm{mg} / \mathrm{L})$ which was significantly higher than stations 2,4 , and 5 ( $p$ value $\leq 0.05$ ).

The trend of soluble reactive phosphorus was similar to $\mathrm{NO}_{3}{ }^{-}$-N where the highest SRP was observed at station 3 $(22.2 \pm 1.9 \mu \mathrm{g} / \mathrm{L})$ and it was significantly higher than stations 2 , 4 , and 5 ( $p$ value $\leq 0.05$ ). The highest TP concentration was found at station $5(85.8 \pm 6.3 \mu \mathrm{g} / \mathrm{L})$ and significantly higher than stations 1,4 , and 6 ( $p$ value $\leq 0.05$ ). Total sulphide ranged from $0.010 \pm 0.000 \mathrm{mg} / \mathrm{L}$ to $0.027 \pm 0.006 \mathrm{mg} / \mathrm{L}$ whereas $\mathrm{H}_{2} \mathrm{~S}$ ranged from $0.003 \pm 0.000 \mathrm{mg} / \mathrm{L}$ to $0.012 \pm 0.000 \mathrm{mg} / \mathrm{L}$. The highest TS and $\mathrm{H}_{2} \mathrm{~S}$ concentrations were found at station 6 . Total sulphide at stations 1,2 , and 3 was significantly lower than stations 4,5 , and 6 ( $p$ value $\leq 0.05)$ whereas $\mathrm{H}_{2} \mathrm{~S}$ at stations $1,3,4$, and 5 was significantly lower than station 6 ( $p$ value $\leq 0.05$ ).

3.3. Sediment Quality. Figure 4 shows that soil texture of the sampling stations was mostly sand (69.9\% to $83.4 \%)$, followed by clay (6.6\% to $26.7 \%)$ and silt ( $0.2 \%$ to $14.8 \%)$. Station 2 had the highest percentage of sand but the lowest percentage of

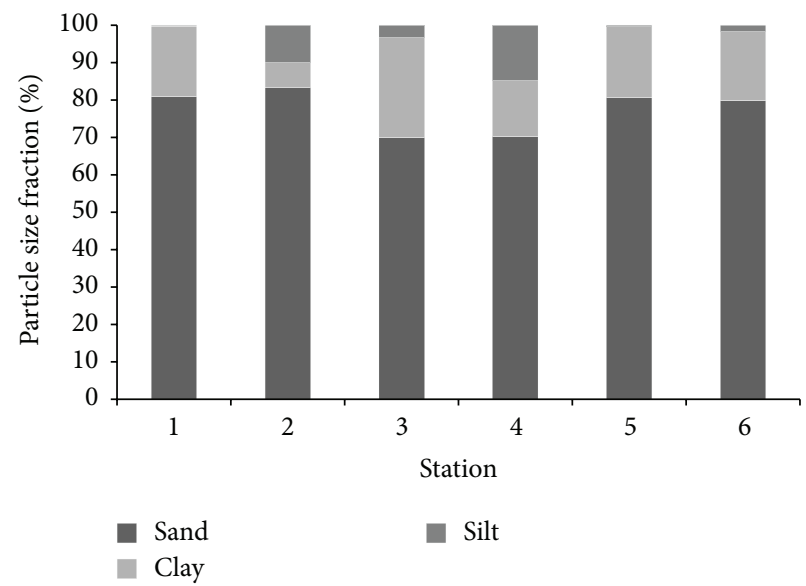

Figure 4: Particle size fraction of sediment collected at the six sampling stations located at the upper reaches of two main tributaries of Batang Baleh.

clay, while station 3 had the lowest percentage of sand but the highest percentage of clay. Station 1 and station 5 had extremely low percentage of silt whereas station 4 had the highest percentage of silt. Figure 5 illustrates the sediment quality of the six sampling stations. Sediment $\mathrm{pH}$ of the study area ranged from $4.80 \pm 0.01$ to $6.11 \pm 0.01$. The lowest $\mathrm{pH}$ value was found at station 3 which was significantly lower than stations 1,2 , and 4 ( $p$ value $\leq 0.05$ ). Stations 4 and 6 had high water content $(\approx 1.83 \%)$ and $\mathrm{OM}(\approx 3.0 \%)$ while stations 1 and 2 had low $\mathrm{OM}(0.1 \%)$ and TOC $(\approx 0.15 \%)$. Water content of stations 4 and 6 was significantly higher than stations 1 and 5 ( $p$ value $\leq 0.05$ ). Organic matter at stations 1 and 2 was significantly lower than stations 4 and 6 ( $p$ value $\leq 0.05$ ) while TOC at stations 1 and 2 was significantly lower than stations 5 and 6 ( $p$ value $\leq 0.05$ ). The highest sediment TN was found at station $1(0.17 \%)$ followed by station $2(0.05 \%)$ which was significantly higher compared to the other stations ( $p$ value $\leq$ $0.05)$ while sediment TP at station $4(0.01 \%)$ was significantly higher than stations 2,3 , and 5 ( $p$ value $\leq 0.05$ ). 


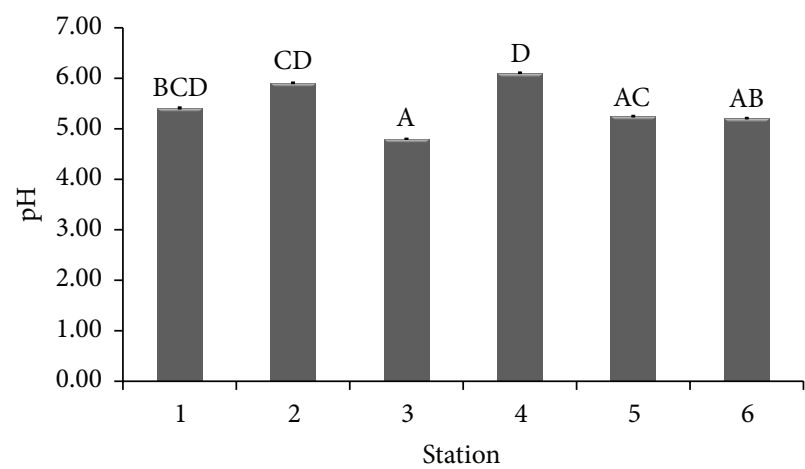

(a)

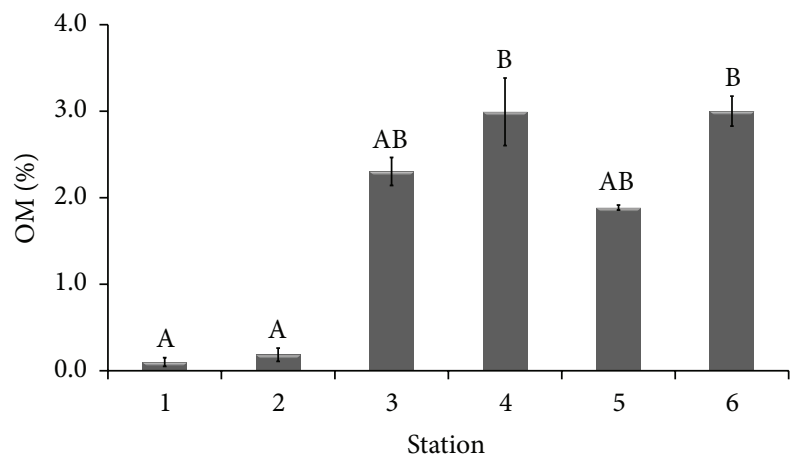

(c)

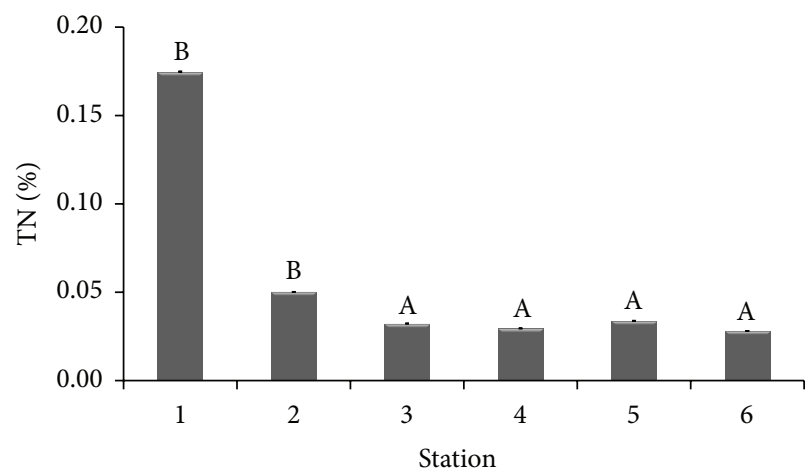

(e)

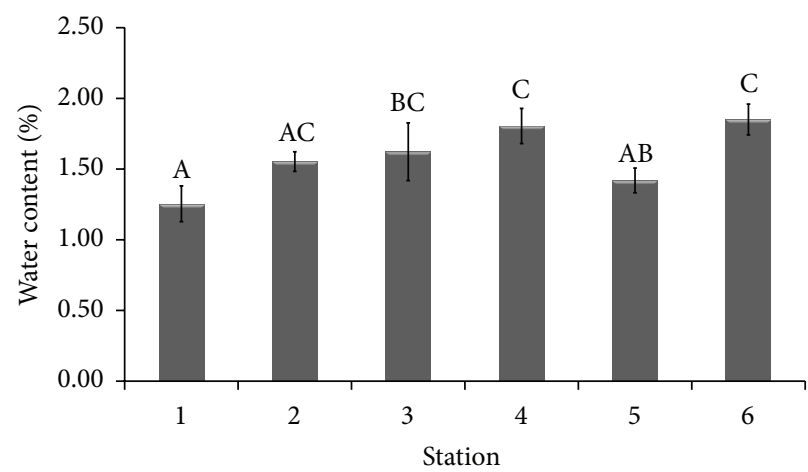

(b)

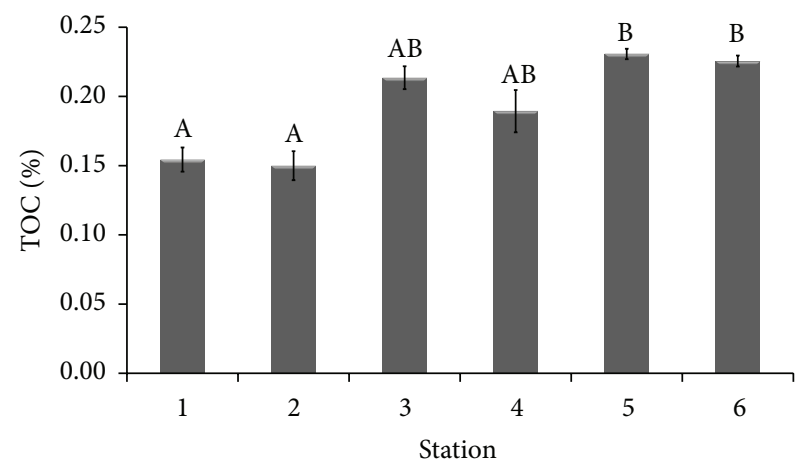

(d)

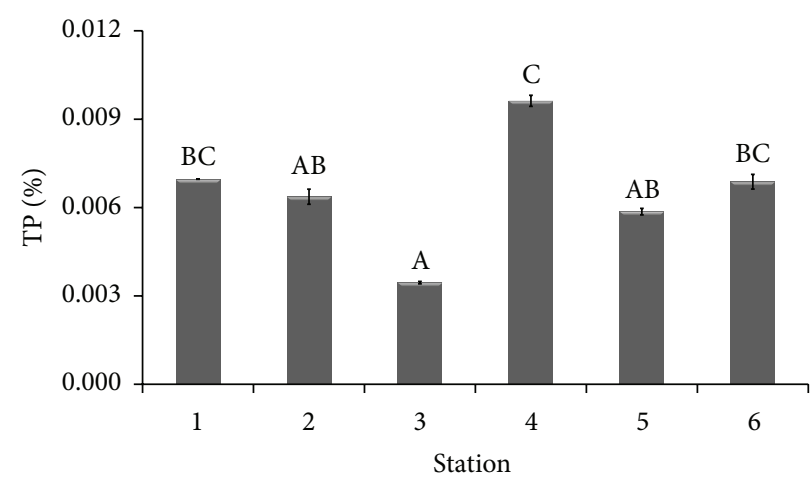

(f)

FIGURE 5: Sediment quality of (a) pH, (b) water content, (c) organic matter (OM), (d) total organic carbon (TOC), (e) total nitrogen (TN), and (f) total phosphorus (TP) collected at the six sampling stations located at the upper reaches of two main tributaries of Batang Baleh (different letters indicate significant difference at $p$ value $\leq 0.05$ ).

3.4. Correlation. Table 2 summarizes the correlation of in situ and ex situ parameters collected from the six sampling stations. Among them, $\mathrm{NO}_{2}{ }^{-}-\mathrm{N}$ had no significant correlation with other parameters. The stream flow velocity was significantly and positively correlated with $\mathrm{DO}(r=+0.90, p$ value $\leq$ $0.05)$ but negatively correlated with COD $(r=-0.93$, $p$ value $\leq 0.05)$. Chl- $a$ was significantly negatively correlated with sediment $\mathrm{pH}$, turbidity, and TSS $(r=-0.81$ to -0.93 , $p$ value $\leq 0.05)$. Positive correlation was found among temperature, TS, and TN $(r=+0.81$ to +0.93 , $p$ value $\leq 0.05)$. TAN was significantly and negatively correlated with sediment TN $(r=$ $-0.85, p$ value $\leq 0.05$ ) but positively correlated with sediment $\mathrm{OM}$ and conductivity value $(r=+0.90$ to $+0.94, p$ value $\leq$
0.05). $\mathrm{NO}_{3}{ }^{-}-\mathrm{N}$ was significantly and positively correlated with SRP $(r=+0.93, p$ value $\leq 0.05)$. TP was significantly and positively correlated with $\mathrm{BOD}_{5}(r=+0.93, p$ value $\leq$ 0.05 ) whereas sediment TP was found to be significantly and positively correlated with $\mathrm{DO}(r=+0.84, p$ value $\leq 0.05)$.

3.5. Cluster Analysis (CA). Cluster analysis (CA) was applied to detect similarities among the sampling stations using the in situ and ex situ water parameters and sediment quality of the stations. A total of 29 variables were subjected to CA. The dendrogram showing the cluster of the sampling stations is presented in Figure 6. The result shows that the six sampling stations can be grouped into three clusters. Cluster 1 consisted 


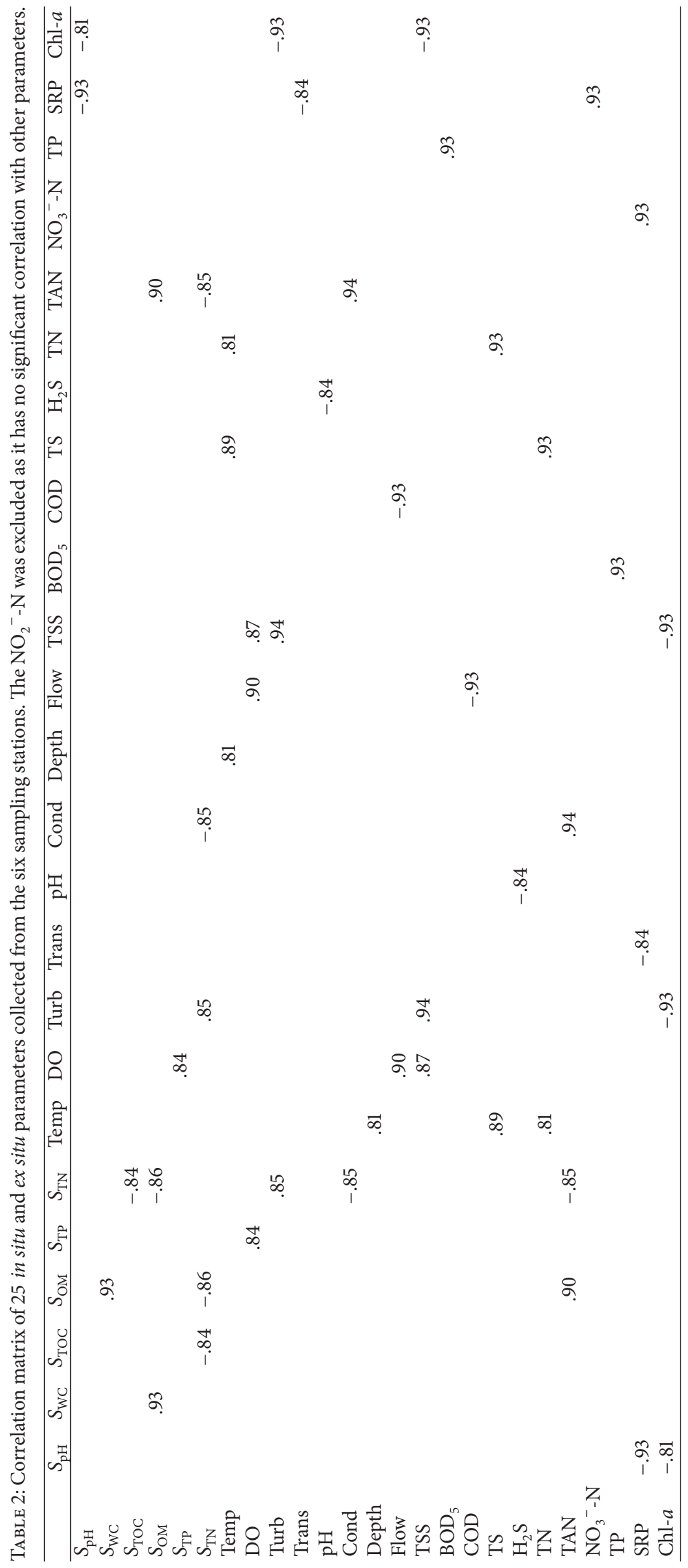




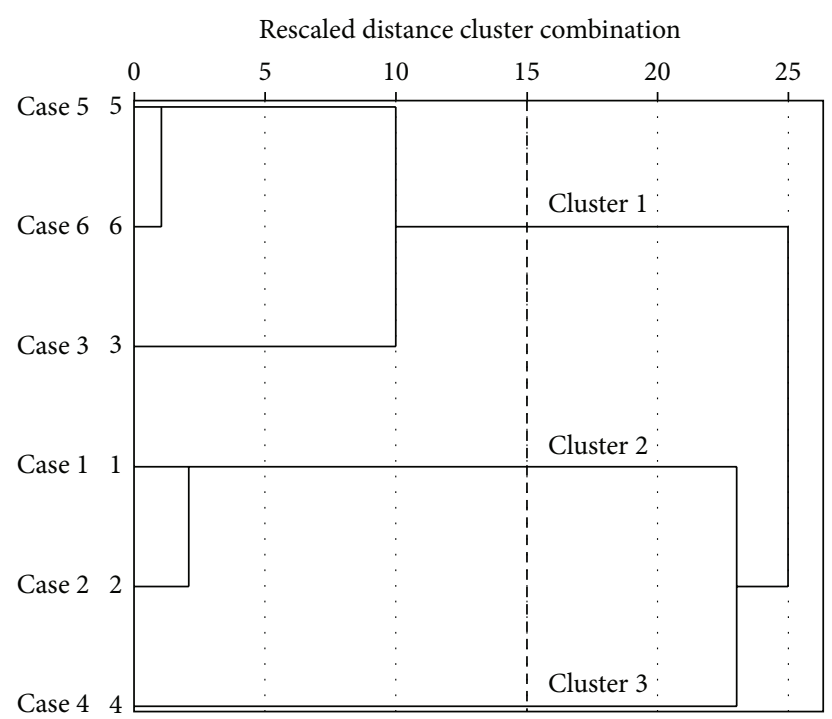

Figure 6: Cluster of the six sampling stations.

of stations 3,5, and 6. Station 4 which is located at the main river of Sg. Gaat is grouped as cluster 3. Cluster 2 consists of stations 1 and 2 which are the tributaries of Sg. Mengiong.

3.6. The Influence of the Rainfall Event. The in situ and ex situ water quality data were also taken at three selected stations after rain in the present study. Table 3 summarizes the significant difference of the parameters before and after rain. Temperature, transparency, and $\mathrm{pH}$ of the sampling stations decreased significantly after the rainfall event ( $p$ value $\leq 0.05$ ) while DO, turbidity, and flow velocity increased significantly ( $p$ value $\leq 0.05$ ). Total suspended solids, $\mathrm{COD}, \mathrm{TN}, \mathrm{NO}_{2}{ }^{-}-\mathrm{N}$, TP, and SRP increased significantly after rain ( $p$ value $\leq 0.05)$ whereas chl- $a$ and TS decreased significantly ( $p$ value $\leq 0.05$ ) after rain.

3.7. Water Quality Index (WQI). All of the sampling stations are classified as Class II according to the water quality index (WQI). Among the six parameters, $\mathrm{pH}$ and TSS are classified as Class I whereas COD at most of the stations are classified as Classes III and IV. The water quality of the three selected stations deteriorated after the rain, particularly station 6 which changed from Class II to Class III. The status of the streams also changed from being "clean" to "slightly polluted" due to the rainfall event. The parameter most influenced by rain was TSS where it changed from Class I to Classes III and IV after the rain (Table 4).

\section{Discussion}

Forestry activities, either forest harvesting or replanting, can modify water and sediment quality in many ways that affect the aquatic habitat and organisms. For instance, canopy removal which exposes forest stream to direct solar radiation can increase water and sediment temperature [36]. In the present study, the significant lower temperature at stations
TABLE 3: Mean difference of in situ and ex situ water quality parameters before and after rain $(N=9)$.

\begin{tabular}{lcc}
\hline Parameters & Mean difference & $p$ value \\
\hline In situ & & \\
Temperature & $-\mathbf{4 . 3}$ & $\mathbf{0 . 0 0 8}$ \\
DO & $\mathbf{+ 0 . 3}$ & $\mathbf{0 . 0 4 7}$ \\
Turbidity & $+\mathbf{4 2 5 . 7}$ & $\mathbf{0 . 0 0 8}$ \\
Transparency & $-\mathbf{2 8 . 6}$ & $\mathbf{0 . 0 0 8}$ \\
pH & $-\mathbf{0 . 5}$ & $\mathbf{0 . 0 0 7}$ \\
Conductivity & +2.9 & 0.859 \\
Depth & -0.1 & 1.000 \\
Flow velocity & $+\mathbf{0 . 4}$ & $\mathbf{0 . 0 0 0}$ \\
\hline Ex situ & & \\
Chlorophyll $a$ & $-\mathbf{0 . 7}$ & $\mathbf{0 . 0 0 8}$ \\
Total suspended solid & $\mathbf{+ 9 5 . 8}$ & $\mathbf{0 . 0 0 8}$ \\
Five-day biochemical oxygen demand & -0.02 & 0.856 \\
Chemical oxygen demand & $+\mathbf{1 9 . 4}$ & $\mathbf{0 . 0 4 9}$ \\
Total nitrogen & $+\mathbf{1 . 5 7 6}$ & $\mathbf{0 . 0 1 1}$ \\
Total ammonia nitrogen & +0.145 & 0.051 \\
Nitrite nitrogen & $\mathbf{+ 0 . 0 0 9}$ & $\mathbf{0 . 0 0 7}$ \\
Nitrate nitrogen & +0.009 & 0.066 \\
Total phosphorus & $\mathbf{+ 5 6 . 2}$ & $\mathbf{0 . 0 0 8}$ \\
Soluble reactive phosphorus & $\mathbf{+ 1 2 . 2}$ & $\mathbf{0 . 0 0 8}$ \\
Total sulphide & $\mathbf{- 0 . 0 1 0}$ & $\mathbf{0 . 0 0 5}$ \\
Unionized hydrogen sulphide & -0.001 & 0.952 \\
\hline Poitve value of & & \\
\hline & &
\end{tabular}

Positive value of mean difference indicates parameter studied increased after rain whereas negative value indicates a decrease after rain. The significant difference at $p$ value $\leq 0.05$ was indicated in bold.

1 and 3 ( $p$ value $\leq 0.05)$ was measured in the morning whereas other stations were measured in the afternoon. The large variation of the forest streams temperature in one day indicates that the logging activities have increased the extent of direct solar radiation of the forest streams, subsequently leading to the significant increase of temperature in the afternoon. Temperature of the forest streams in the present study is relatively higher than the Berasau River in Johor, Malaysia, $\left(25.23-26.47^{\circ} \mathrm{C}\right)$ which is also subjected to logging activities [12] but is relatively lower than the peat swamp forest that was converted into oil palm plantation (26.85$32.90^{\circ} \mathrm{C}$ ) in Batang Igan, Sibu, Sarawak [37].

Logging can also lead to increased sedimentation of streams [36]. Slight sedimentation of the streams was observed in the field during sample collection. The presence of logging activities renders the higher turbidity and TSS values observed at stations 1, 2, 4, and 6 compared to stations 3 and 5 which have the lowest turbidity and TSS values due to inactive logging at those stations. However, overall all streams were still considered clear with high transparency and low turbidity $(<10 \mathrm{NTU})$ and TSS $(<20 \mathrm{mg} / \mathrm{L})$ values indicating that logging activities did not increase the sedimentation of the streams to a polluted level when there was no rainfall event. Similarly, [38] demonstrated that there was no significant pollution through erosion occurring at the peat swamp forest that was converted into oil palm plantation although 
TABLE 4: Classification of water quality of the six sampling stations before and after rain according to WQI.

\begin{tabular}{lcccccccc}
\hline Station & AN & BOD $_{5}$ & COD & DO & pH & TSS & WQI & Status \\
\hline 1 & II & II & III & II & I & I & II & Clean \\
2 & II & III & III & II & I & I & II & Clean \\
3 & III & III & III & II & I & I & II & Clean \\
4 & III & III & II & I & I & I & II & Clean \\
5 & II & III & IV & II & I & I & II & Clean \\
6 & III & III & IV & II & I & I & II & Clean \\
\hline $4 \mathrm{r}$ & III & III & IV & I & I & III & II & Slightly polluted \\
$5 \mathrm{r}$ & III & III & III & I & I & III & II & Slightly polluted \\
$6 \mathrm{r}$ & III & III & IV & II & II & IV & III & Slightly polluted \\
\hline
\end{tabular}

r: after rain.

the TSS value of the oil palm plantation site is higher than the natural peat swamp forest. In spite of that, the significant correlation of chl- $a$ ( $p$ value $\leq 0.05$ ) with turbidity and TSS indicates that light penetration is the main factor in regulating the chl- $a$ concentration in the present forest streams.

There is no sign of acidification of the stream water $(\mathrm{pH}$ $\geq 7)$ and all streams are well-aerated (DO $\geq 6 \mathrm{mg} / \mathrm{L})$. DO is significantly correlated with stream flow velocity ( $p$ value $\leq$ 0.05 ) in the present study indicating reaeration of the faster flowing stream. According to the WQI, the $\mathrm{pH}$ values at all six sampling stations are classified as Class I while DO is classified as Class I and/or Class II. Besides, $\mathrm{NO}_{2}{ }^{-} \mathrm{N}, \mathrm{NO}_{3}{ }^{-}-$ $\mathrm{N}, \mathrm{SRP}$, and TP concentrations in the present study were also classified as Class I according to the National Water Quality Standards for Malaysia [35]. $\mathrm{H}_{2} \mathrm{~S}$ concentration in the present study is also lower than the threshold of $0.05 \mathrm{mg} / \mathrm{L}$ in drinking water [39].

However, $\mathrm{BOD}_{5}$ values at all stations are classified as Class III except station 1, and AN values at stations 3, 4, and 6 are classified as Class III while COD values at stations 5 and 6 are classified as Class IV. The significant negative correlation between stream flow velocity and COD ( $p$ value $\leq 0.05$ ) indicates that the organic matter is accumulated at the slow flowing stream; in particular, station 6 with slow flow was found significantly higher in OM and TOC in sediments ( $p$ value $\leq 0.05$ ). Significantly lower sediment TN was observed at stations 3 to 6 compared to stations 1 and 2 ( $p$ value $\leq 0.05$ ) indicating the loss of nitrogen from sediment to water. This is further proven by the significantly negative correlation between sediment TN and TAN concentration in water ( $p$ value $\leq 0.05)$. Logging can lead to increased mineralization and nitrification, with a subsequent loss of minerals and nutrients from soil into water [6]. Significant positive correlation between TN and TS ( $p$ value $\leq 0.05)$ and positive correlation between TP and $\mathrm{BOD}_{5}$ ( $p$ value $\leq$ 0.05 ) suggested that the pollution was derived from the same source. Besides, SRP was significantly correlated with $\mathrm{NO}_{3}{ }^{-}$$\mathrm{N}$ ( $p$ value $\leq 0.05)$ indicating that the inorganic pollution was from the same source.

According to CA, station 4 which is located at the main river of Sg. Gaat is grouped as an independent cluster from other tributaries. Stations 1 and 2 which are located at the tributaries of Sg. Mengiong are grouped as the same cluster. Stations 5 and 6 which are located at the tributaries of Sg. Gaat are grouped as another cluster. However, station 3 which is located at one of the tributaries of Sg. Mengiong is grouped together with the two tributaries of Sg. Gaat (stations 5 and 6) due to its proximity to those stations. We can see from the CA that the characteristic of the main river is different from the tributaries and the tributaries of Sg. Gaat are different from the tributaries of Sg. Mengiong, except for Sg. Entajum.

Overall, the WQIs of the six sampling stations are classified as Class II which are considered clean and can be used as water supply after conventional treatment. Similarly, the Berasau River in Johor, Malaysia, which is also subjected to logging activities is classified between Classes II (good) and III (moderate) of river water quality [12]. Also, the qualities of surface waters draining from a secondary forest and an oil palm plantation in the Lower Kinabatangan River catchment, Sabah, Malaysia, fall into Class II as well [40]. However, in the present study, the water quality of the forest streams deteriorated significantly after rain $(p$ value $\leq 0.05)$. After the rainfall event, turbidity, TSS, and most of the nutrients increased significantly with the stream flow velocity ( $p$ value $\leq 0.05$ ). Suspended sediment and chemical oxygen demand were also found higher during the wet season in the Lower Kinabatangan River catchment, Sabah, Malaysia [40]. The deterioration of water quality is most likely due to the sediment inflow from the logging areas coupled with resuspended stream sediment. On the other hand, after rain, stream DO was significantly higher due to the higher velocity of the water which increases reaeration of the stream water. In addition, temperature which was significantly lower ( $p$ value $\leq 0.05$ ) indicates cooler water which holds more oxygen. According to WQI, TSS was the parameter that was influenced the most by the rainfall event where it changed from Class I to Class III and/or IV at stations 4, 5, and 6 after the rain. Before the rain, logging activities had minimal impact on the increase of sediment in the water column of the streams as indicated by low turbidity and TSS. However, the impact of the logging activities on water column sediment was noticeable after the rain. The WQI of station 6 which is located downstream of active logging activities changed from Class II to Class III. The status of all three sampling stations 
also changed from "clean" to "slightly polluted" after rain. The impact of logging resulting in soil erosion and subsequently high turbidity in stream water was also reported in other rivers in the state, where in the Belepeh River that flows into Bakun Dam in the upper Rajang River, increase of turbidity from 8.5 to 126.8 NTU was observed resulting in a change of Class II compliance to noncompliance [41]. In addition, the Kebhor River, a tributary of the Balui River, was also reported to be high in turbidity (94 NTU) due to soil erosion as a result of logging [42].

\section{Conclusions}

Forest streams in the present study are well-oxygenated with $\mathrm{pH}$ values that are nearly neutral. Prior to a rainfall event, the water is high in transparency and low in turbidity and TSS values. Soil texture of the stream sediment is mostly sand, followed by clay and silt. However, logging activities around the study area have an impact on the water and sediment quality of the forest streams. Canopy removal in the study area renders significant changes of stream temperature over a day. Suspended solids are higher at stations with the presence of logging activities compared to the stations with inactive logging activities. Nutrients concentrations in the present study complied with the national and/or international standard except for $\mathrm{AN}, \mathrm{BOD}_{5}$, and $\mathrm{COD}$. WQI indicated that, without rain, the forest streams in the present study are still of good quality but suffer from organic pollution with high $\mathrm{AN}, \mathrm{BOD}_{5}$, and COD. Nitrogen loss from sediment to water and accumulation of OM and TOC were also observed in the study area. The water quality of the forest streams deteriorates after a rainfall event where suspended solids are the most affected parameter. This calls for appropriate management of forests to reduce deterioration of water quality after rainfall events.

\section{Competing Interests}

The authors declare that they have no competing interests.

\section{Acknowledgments}

The authors appreciate the financial support provided by the Sarawak Energy Berhad through GL(F07)/SEB/1C/2013(14) and the facilities provided by Universiti Malaysia Sarawak.

\section{References}

[1] Sarawak Timber Industry Development Corporation, Export Statistics of Timber and Timber Products Sarawak 2012, STIDC, Sarawak, Malaysia, 2015.

[2] Malaysian Timber Industry Board, E-Statistics-Export, MTIB, Kuala Lumpur, Malaysia, 2015.

[3] J. Hon and S. Shibata, "A review on land use in the Malaysian state of Sarawak, Borneo and recommendations for wildlife conservation inside production forest environment," Borneo Journal of Resource Science and Technology, vol. 3, no. 2, pp. 2235, 2013.
[4] J. Bryan, P. Shearman, J. Ash, and J. B. Kirkpatrick, "Estimating rainforest biomass stocks and carbon loss from deforestation and degradation in Papua New Guinea 1972-2002: best estimates, uncertainties and research needs," Journal of Environmental Management, vol. 91, no. 4, pp. 995-1001, 2010.

[5] R. A. Dahlgren, "Effects of forest harvest on stream-water quality and nitrogen cycling in the Caspar Creek watershed," USDA Forest Service Gen. Tech. Rep. PSW-GTR-168, USDA, 1998.

[6] S. H. Ensign and M. A. Mallin, "Stream water quality changes following timber harvest in a coastal plain swamp forest," Water Research, vol. 35, no. 14, pp. 3381-3390, 2001.

[7] F. Gökbulak, Y. Serengil, S. Özhan, N. Özyuvaci, and N. Balci, "Effect of timber harvest on physical water quality characteristics," Water Resources Management, vol. 22, no. 5, pp. 635-649, 2008.

[8] M. Palviainen, L. Finér, A. Laurén, T. Mattsson, and L. Högbom, "A method to estimate the impact of clear-cutting on nutrient concentrations in boreal headwater streams," Ambio, vol. 44, no. 6, pp. 521-531, 2015.

[9] J. Schelker, K. Eklöf, K. Bishop, and H. Laudon, "Effects of forestry operations on dissolved organic carbon concentrations and export in boreal first-order streams," Journal of Geophysical Research: Biogeosciences, vol. 117, no. 1, Article ID G01011, 12 pages, 2012.

[10] H. L. Lee, H. L. Koh, and H. A. Al'rabia'ah, "Predicting soil loss from logging in Malaysia," in GIS and Remote Sensing in Hydrology, Water Resources and Environment (IAHS Proceedings \& Reports), Y. Chen, K. Takara, I. D. Cluckie, and F. H. De Smedt, Eds., vol. 289, pp. 308-315, International Association of Hydrological Sciences, Oxfordshire, UK, 2004.

[11] T. Gomi, R. C. Sidle, S. Noguchi, J. N. Negishi, A. R. Nik, and S. Sasaki, "Sediment and wood accumulations in humid tropical headwater streams: effects of logging and riparian buffers," Forest Ecology and Management, vol. 224, no. 1-2, pp. 166-175, 2006.

[12] A. Nor Zaiha, M. S. Mohd Ismid, Salmiati, and M. S. Shahrul Azri, "Effects of logging activities on ecological water quality indicators in the Berasau River, Johor, Malaysia," Environmental Monitoring and Assessment, vol. 187, no. 8, article 493, 2015.

[13] M. W. Beck, A. H. Claassen, and P. J. Hundt, "Environmental and livelihood impacts of dams: common lessons across development gradients that challenge sustainability," International Journal of River Basin Management, vol. 10, no. 1, pp. 73-92, 2012.

[14] D. de Andrade Cunha and L. V. Ferreira, "Impacts of the Belo Monte hydroelectric dam construction on pioneer vegetation formations along the Xingu River, Pará State, Brazil," Brazilian Journal of Botany, vol. 35, no. 2, pp. 159-167, 2012.

[15] H. Guo, Q. Hu, Q. Zhang, and S. Feng, "Effects of the Three Gorges Dam on Yangtze River flow and river interaction with Poyang Lake, China: 2003-2008," Journal of Hydrology, vol. 416417, pp. 19-27, 2012.

[16] Q. G. Wang, Y. H. Du, Y. Su, and K. Q. Chen, "Environmental impact post-assessment of dam and reservoir projects: a review," Procedia Environmental Sciences, vol. 13, pp. 1439-1443, 2012.

[17] M. Wiatkowski, "Influence of słup dam reservoir on flow and quality of water in the Nysa Szalona river," Polish Journal of Environmental Studies, vol. 20, no. 2, pp. 469-478, 2011.

[18] Q. Lin, "Influence of dams on river ecosystem and its countermeasures," Journal of Water Resource and Protection, vol. 03, no. 01, pp. 60-66, 2011. 
[19] Y. Yi, Z. Yang, and S. Zhang, "Ecological influence of dam construction and river-lake connectivity on migration fish habitat in the Yangtze River basin, China," Procedia Environmental Sciences, vol. 2, no. 5, pp. 1942-1954, 2010.

[20] W. Wildi, "Environmental hazards of dams and reservoirs," Near Curriculum in Natural Environmental Science, vol. 88, pp. 187197, 2010.

[21] X. Li, S. Dong, Q. Zhao, and S. Liu, "Impacts of Manwan Dam construction on aquatic habitat and community in Middle Reach of Lancang River," Procedia Environmental Sciences, vol. 2, no. 5, pp. 706-712, 2010.

[22] G. L. Wei, Z. F. Yang, B. S. Cui et al., "Impact of dam construction on water quality and water self-purification capacity of the Lancang River, China," Water Resources Management, vol. 23, no. 9, pp. 1763-1780, 2009.

[23] S.-K. Selvaradjou, L. Montanarella, O. Spaargaren, D. Dent, N. Filippi, and S. Dominik, European Digital Archive of Soil Maps (EuDASM)_Metadata of the Soil Maps of Asia, Office of the Official Publications of the European Communities, Luxembourg City, Luxembourg, 2005.

[24] Forest Department Sarawak, Major Forest Types in Sarawak, 2016, http://www.forestry.sarawak.gov.my/modules/web/pages .php? mod=webpage\&sub=page\&id=638.

[25] Y. L. Tie, Soil Classification in Sarawak, Department of Agriculture Sarawak, Kuching, Malaysia, 1982.

[26] Chemsain Konsultant Sdn Bhd, "Brief project. Environmental Impact Assessment (EIA) as part of the feasibility study for the proposed Baleh hydroelectric project," Tech. Rep., 2008.

[27] D. P. Dykstra and Elias, Ex-Post Evaluation of PD 104/90 Rev. 2 (F) and PD 26/96 Rev. 4 (F)-Studies of the Management Standards of Hill Dipterocarp Forests in Sarawak from a Watershed Point of View, Phase I and II (Malaysia), International Tropical Timber Organization, Yokohama, Japan, 2003.

[28] D. Jenkins, J. J. Connors, and A. E. Greenberg, Standard Methods for the Examination of Water and Wastewater, American Public Health Association, Washington, DC, USA, 21st edition, 2005.

[29] Hach, Hach Water Analysis Handbook, Hach Company, Loveland, Colo, USA, 2015.

[30] G. W. Thomas, "Soil pH and soil acidity", in Methods of Soil Analysis. Part 3. Chemical Methods, D. L. Sparks, A. L. Page, P. A. Helmke, and R. H. Loeppert, Eds., pp. 475-490, Soil Science Society of America, American Society of Agronomy, Madison, Wis, USA, 1996.

[31] W. H. Gardner, "Water content," in Methods of Soil Analysis. Part 1. Physical and Mineralogical Methods, A. Klute, Ed., pp. 493-544, Soil Science Society of America, American Society of Agronomy, Madison, Wis, USA, 1986.

[32] D. W. Nelson and L. E. Sommers, "Total carbon, organic carbon, and organic matter," in Methods of Soil Analysis. Part 3. Chemical Methods, D. L. Sparks, A. L. Page, P. A. Helmke, and R. H. Loeppert, Eds., pp. 961-1010, Soil Science Society of America, American Society of Agronomy, Madison, Wis, USA, 1996.

[33] S. Kuo, "Phosphorus," in Methods of Soil Analysis. Part 3. Chemical Methods, D. L. Sparks, A. L. Page, P. A. Helmke, and R. H. Loeppert, Eds., pp. 869-919, Soil Science Society of America, American Society of Agronomy, Madison, Wis, USA, 1996.

[34] G. W. Gee and J. W. Bauder, "Particle-size analysis," in Methods of Soil Analysis. Part 1. Physical and Mineralogical Methods, A. Klute, Ed., pp. 383-411, Soil Science Society of America, American Society of Agronomy, Madison, Wis, USA, 1986.
[35] Department of Environment, Malaysia Environmental Quality Report 2014, DOE, Kuala Lumpur, Malaysia, 2015.

[36] S. Fulton and B. West, "Forestry impacts on water quality," in Southern Forest Resource Assessment, D. N. Wear and J. G. Greis, Eds., chapter 21, p. 635, U.S. Department of Agriculture, Forest Service, Southern Research Station, Asheville, NC, USA, 2002.

[37] N. Rosli, S. Gandaseca, J. Ismail, and M. I. Jailan, "Comparative study of water quality at different peat swamp forest of Batang Igan, Sibu Sarawak," American Journal of Environmental Sciences, vol. 6, no. 5, pp. 416-421, 2010.

[38] S. Gandaseca, N. Rosli, M. Shawkat Hossain, and C. Imam Arianto, "Assessment of oil palm plantation and tropical peat swamp forest water quality by multivariate statistical analysis," American Journal of Environmental Sciences, vol. 10, no. 4, pp. 391-402, 2014.

[39] World Health Organization, Hydrogen Sulfide in DrinkingWater, World Health Organization, Geneva, Switzerland, 2003.

[40] S. Harun, R. Dambul, M. H. Abdullah, and M. Mohamed, "Spatial and seasonal variations in surface water quality of the Lower Kinabatangan River Catchment, Sabah, Malaysia," Journal of Tropical Biology and Conservation, vol. 11, pp. 117-131, 2014.

[41] T. Y. Ling, L. Nyanti, and A. S. John Masion, "Water quality of rivers that flow into Bakun hydroelectric dam reservoir, Sarawak, Malaysia," ESTEEM Academic Journal, vol. 11, no. 1, pp. 9-16, 2015.

[42] L. Nyanti, T. Y. Ling, and J. Grinang, "Physico-chemical characteristics in the filling phase of Bakun hydroelectric reservoir, Sarawak, Malaysia," International Journal of Applied Science and Technology, vol. 2, no. 6, pp. 92-101, 2012. 

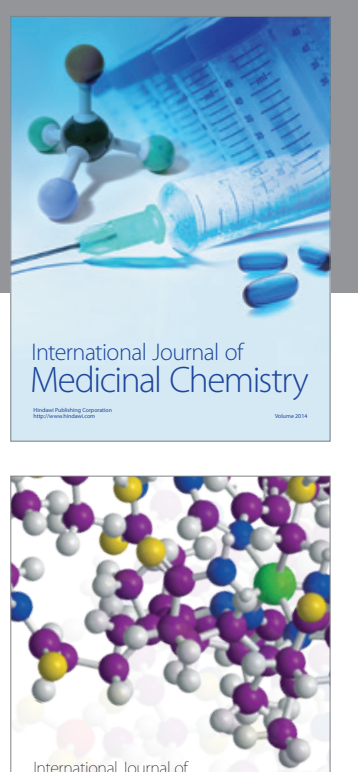

Carbohydrate Chemistry

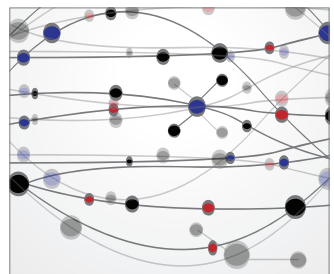

The Scientific World Journal
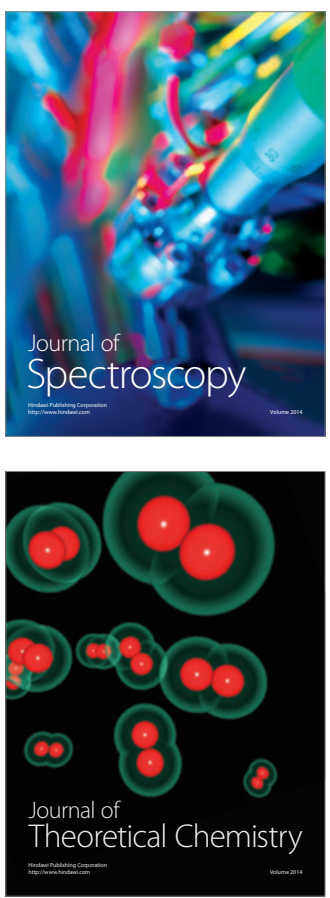
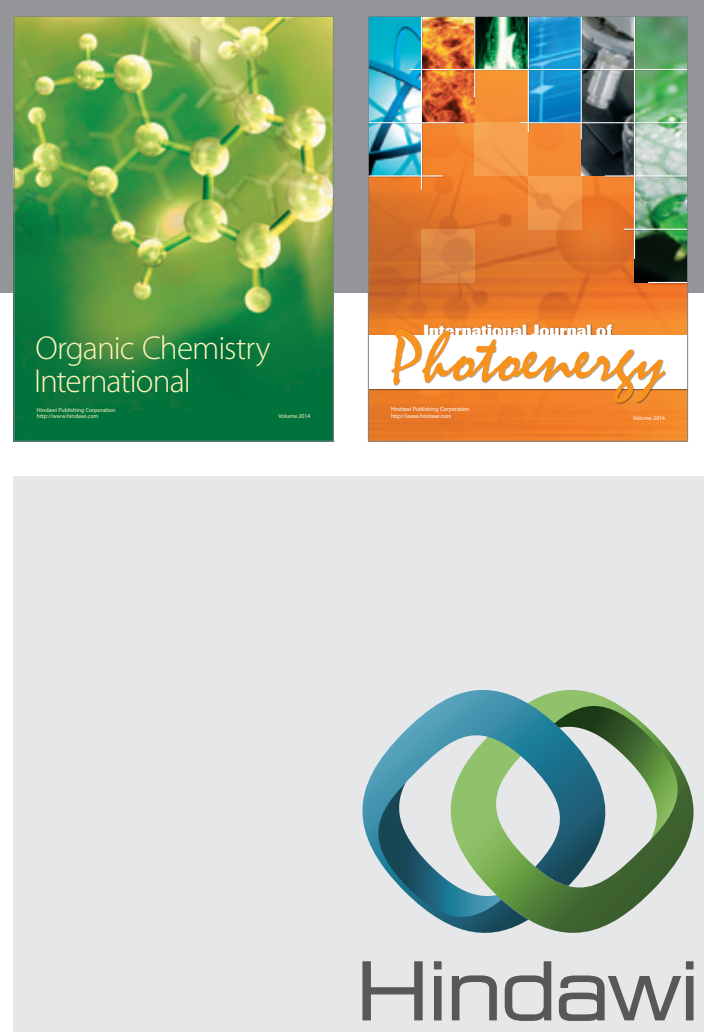

Submit your manuscripts at

http://www.hindawi.com

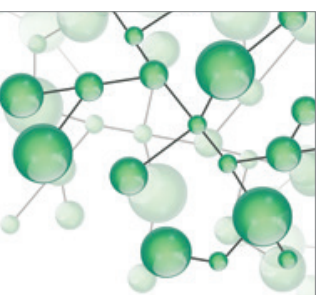

International Journal of

Inorganic Chemistry

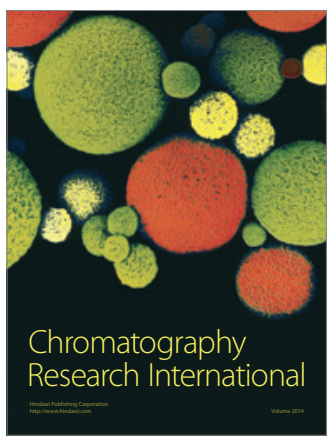

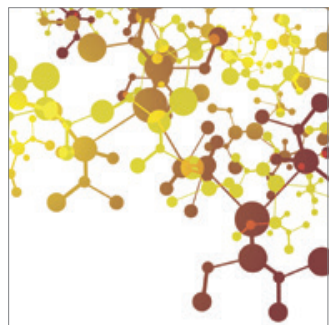

Applied Chemistry
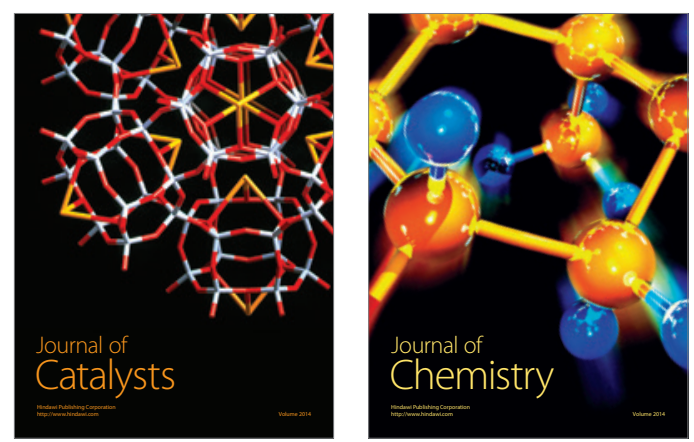
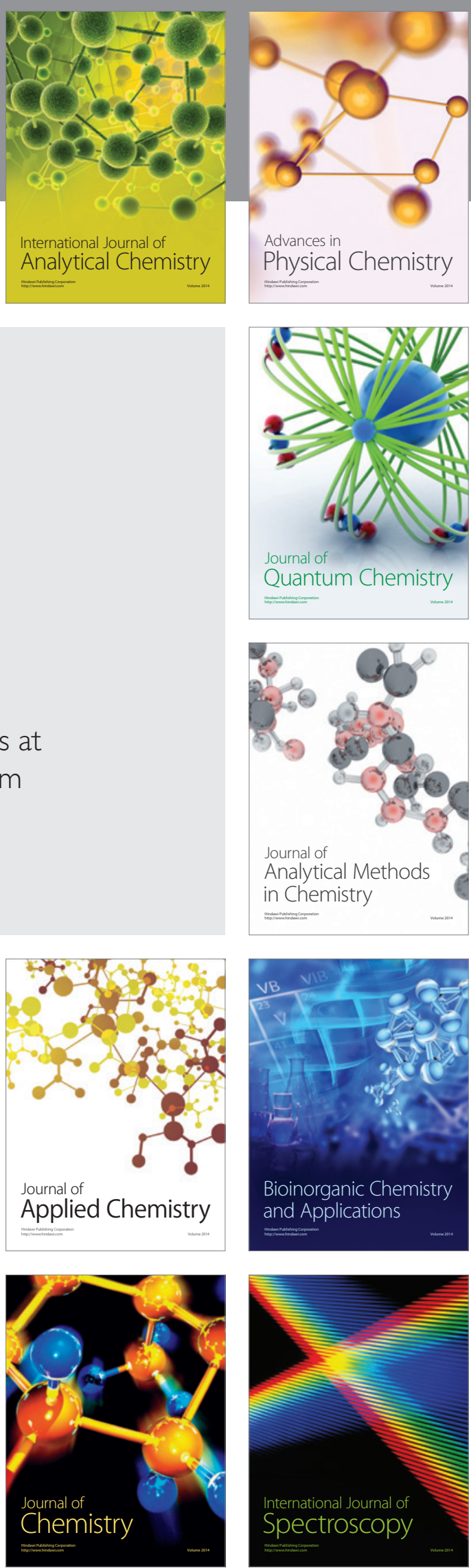